\title{
PENYIMPANGAN PERILAKU SEKS WARIA DALAM NOVEL TAMAN API KARYA YONATHAN RAHARDJO
}

\author{
Lusy Novitasari \\ Program Studi Pendidikan Bahasa dan Sastra Indonesia \\ Jurusan Bahasa dan Seni, STKIP PGRI Ponorogo \\ Lucydheny77@gmail.com
}

\begin{abstract}
Abstrak
Salah satu realitas sosial yang dianggap masalah dalam amsyarakat dan menjadi fenomena adalah kederadaan kaum waria. Waria dianggap sebagai perusak moral, masalah sosial, kesehatan, dan patologi sosial. Terdeskriminasinya kaum waria dari masyarakat secara umum menjadikan kehidupan kaum waria tidak banyak diketahu oleh khalayak. Waria dengan segala gaya hidupnya sebagian besar masyarakat menganggap sebagai sebuah penyimpangan. Penelitian ini menitik beratkan pada penyimpangan perilaku seksual waria dalam novel Taman Api karya Yonathan Rahardjo. Desain penelitian yang digunakan adalah deskriptif kualitatif . Data pada penelitian ini berupa hasil telaah dari novel Taman Api Karya Yonathan Rahardjo. Sumber data primer berupa kalimat dalam novel Taman Api karya Yonathan Rahardjo. Sumber data sekunder adalah sumber data kepustakaan yaitu berupa buku, jurnal, artikel ilmiah. Teknik pengumpulan data menggunakan teknik Content analysis,. Teknik validitas data mempergunakan teknik trianggulasi data atau sumber.Teknik analisis adalah analisis model interaktif (Interactive Model Analysis). Hasil penelitian ini menunjukkan dalam novel Taman Api terdapat (a) seks sesama jenis, (b) dunia prostitusi, dan (c) rekontruksi tubuh.
\end{abstract}

Kata kunci: penyimpangan perilaku, seks, waria

\begin{abstract}
One of the social reality which is considered a problem in society and become a phenomenon is the presence of transvestites. Transgender is considered a moral destroyer, social problems, health, and social pathology. The discrimination of transvestites from society in general makes the lives of transvestites not known to many audiences. Transgender with all his lifestyle most people consider as a deviation. This research focuses on the deviation of transsexual sexual behavior in the novel Taman Api by Yonathan Rahardjo. The research design used is descriptive qualitative. The data in this study is the result of a study of the novel Taman Api by Yonathan Rahardjo. The primary data source is a sentence in the novel Taman Api by Yonathan Rahardjo. Secondary data source is library data source that is in the form of book, journal, scientific article. Data collection techniques using Content analysis techniques. Data validity technique using data or source triangulation technique. Analyze technique is interactive model analysis (Interactive Model Analysis). The results of this study show that in Taman Fire novels there are (a) same sex, (b) world of prostitution, and (c) body reconstruction.
\end{abstract}

Keywords: deviation behavior, sex, transvestites

\section{PENDAHULUAN}

Sastra merupakan karya krestif imajinatif manusia dalam bidang seni dengan menggunakan media bahasa. Sebagai hasil karya, sastra tidak hanya didukung unsur-unsur intrinsik yang membangun ceritanya. Karya sastra baik berupa novel, cerpen, puisi, maupun naskah drama mengandung unsur-unsur dari luar (ekstrinsik), baik dalam aspek psikologis, antropologis maupun sosiologis karena karya sastra diciptakan oleh sastrawan yang 
merupakan anggota masyarakat dan karya sastra dinikmati oleh masyarakat pula. Oleh sebab itu, karya sastra bisa dipandang sebagai cermin kehidupan masyarakat yang di dalamnya terdapat berbagai pelik masalah.

Dunia realitas merupakan bahan karya sastra, dan selanjutnya akan diolah oleh sastrawan menjadi sebuah karya seni yang sesuai dengan apa yang dikehendakinya terkait dengan konflik, keunikan fenomena dalam masyarakat dan berbagai hal menarik dari masyarakat. Pernyataan tersebut senada dengan apa yang dikemukakan oleh Renne Wellek dan Austin Warren (1990: 109) bahwa sastra menyajikan kehidupam, dan kehidupan tersebut sebagian besar terdiri atas kenyataan sosial, walaupun karya sastra itu juga dipandang suatu gejala sosial. Terkait ungkapan di atas, Sadewa (2012: 65-66) mengemukakan bahwa sebuah karya sastra bisa dibahas atau diteliti melalui berbagai pendekatan yang berkaitan dengan segala hal yang menyangkut kehidupan manusia atau masyarakat.

Apabila sastra dipandang sebagai cerminan dari kehidupan masyarakat, maka wajar jika teks sastra dikaji dengan menggunakan pendekatan sosiologi sastra. Tidak dapat dipungkiri sebagai anggota masyarakat sastrawan dalam proses penciptaan hingga lahirnya sebuah karya baik itu novel, cerpen, puisi, dan begitu juga naskah drama sangat dipengaruhi oleh keadaan sosial dan masyarakat yang melingkupinya. Hal-hal yang mempengaruhi dalam proses kreatifnya itu bisa karena latar belakang agama, sosial, budaya, bahkan cerita hidup dari sastrawan itu sendiri.

Penelitian sosiologi sastra merupa-kan upaya melihat fenomena sosial secara empiris dengan menggunakan teks sastra sebagai cerminan fakta sosial (Sariban: 118).
Pendekatan sosiologi sastra dipakai sebagai bahan untuk menganalisis sebuah karya seni merupa-kan upaya untuk melihat sebuah realita sosial ataupun fenomena-fenomena yang berkembang dalam masyarakat, dalam hal ini menggunakan novel sebagai objek kajiannya.

Novel adalah wujud dari salah satu karya sastra yang banyak diminati oleh pembaca. Novel berdasarkan pendapat dari Nurgiyantoro merupakan karya sastra yang mengungkapkan aspek-aspek kemanusiaan yang lebih men-dalam dan disajikan dengan halus (1995: 9). Novel dianggap paling dominan dalam menampilkan unsurunsur cerita yang paling lengkap, memiliki media paling luas, dan bahasa novel cenderung bahasa sehari-jari yang umum digunakan dalam masyarakat. Nurgiyantoro (1995:

11) mengemukakan bahwa novel dapat mengemukakan sesuatu secara bebas, menyajikan sesuatu secara lebih banyak, lebih rinci, lebih detil, dan lebih banyak melibatkan berbagai permasalahan yang lebih kompleks.

Novel yang baik dibaca untuk penyempurnaan diri. Novel yang baik adalah novel yang isinya dapat memanusiakan para pembacanya. Sejalan dengan pendapat Isnaniah, Waluyo, Sayuti, Andayani (2013: 197-198) yang mengemukkan bahwa Novel is one of the literary works which is interesting to study. Its presence means to explore the aesthetics values, and is expected to realize universal values prevailing in society, such as religious values, educational, humanitarian, moral, ethical, and others. The presence of a novel certainly cannot be separated fromthe socio-cultural background of the author's life and ideology, the environment when the creation of the novel, and the reader's society who will appreciate the work. Pernyataan yang 
dikemukakan ahli dalam Journal of Education and Practice menegaskan bahwa sebagai sebuah karya sastra yang baik, novel (khususnya) tidak hanya diciptakan sebagai karya yang tidak memiliki fungsi. Fungsi tersebut juga tidak hanya berhenti sebagai fungsi hiburan semata. Karya yang baik adalah karya yang bisa memanusiakan manusia.

Cerita yang tertuang dalam novel menggambarkan berbagai pelik kehidupan masyarakat. Umumnya terdapat konflik sosial yang sudah menjadi rahasia umum, diketahui dan dapat dirasakan bahwa suatu yang abnormal itu ada. Ketimpanganketimpangan sosial (abnormal) dalam novel tersebut digambarkan dalam perilaku tokoh atau sering disebut sebagai penokohan. Senada dengan yang dikemukakan Endraswara (2013: 41) bahwa novel adalah gambaran fiktif kehidupan manusia. Perilaku sendiri memiliki pengertian sebagai tanggapan atau reaksi individu terhadap rangsangan maupun lingkungan.

Artikel ini menjadikan cerita dalam novel Taman Api sebagai objek kajian penelitian. Penggambaran perilaku tokoh yang terdapat pada novel Taman Api mengupas perilaku-perilaku tokoh yang menitik beratkan pada kehidupan atau perilaku para waria baik yang dapat dikatan sebuah ketimpangan ataupun yang dianggap normal dan berbagai macam problem yang melingkupinya. Novel Taman Api digambarkan oleh pengarang kaya akan konflik yang menarik untuk dikaji, khususnya menguak bagaimana kehidupan waria yang penuh dengan stikma negative seperti anggapan bahwa waria adalah patologi sosial, perusak moral, pencemar kesehatan, dan bahkan menyalahi kodrat dari Tuhan.

Waria dilihat dari definisi sosiologis merupakan transgender
(Puspitosari.dan Pujileksono, 2005: 9). Transgender biasa dipahami sebagai perempuan yang terperangkap dalam tubuh laki-laki. Para waria sering mempresentasikan dirinya sebagai wanita yang terkurung dalam tubuh laki-laki dan memiliki ciri bersolek atau berdandan serta memakai pakaian layaknya wanita. Bahkan, perilaku yang dianggap menyimpang dalam masyarakat dan ada pada waria ialah bagaimana ia bersikap, berjalan, bertutur, serta jenis perilaku atau orientasi seksual mereka yang lebih memiliki kecenderungan menyukai lakilaki.

Dari sisi psikologis, waria dikatakan sebagai kaum transeksual atau seseorang yang memiliki wujud jasmani laki-laki namun secara psikis memiliki kecenderungan berperingai sebagai perempuan. Secara seksual waria menyukai laki-laki, orientasi seksual waria sama dengan homoseks. Dilain pihak, homoseks berbeda dengan waria yang mengubah tubuh, alat kelamin, dan perilakunya layaknya perempuan, sedangkan homoseks hanya memiliki ketertarikan seks pada sesama jenis. Pada wanita biasa dikatakan sebagai lesbian.

Truong menjelaskan bahwa seks dalam kehidupan manusia menjadi bagian yang sangat penting, karena perilaku seksual akan mempengaruhi kontruksi sosial (dalam Koeswinarno, 2004: 53). Kaum waria memiliki perilaku dan kebutuhan seks yang berbeda dengan masyarakat pada umumnya. Kaum waria memiliki orientasi seks tidak sesuai dengan penampilan jasmaniah mereka, dimana laki-laki berpenampilan layaknya perempuan dan dalam perilaku seks pun kaum waria cenderung menyukai sesama jenis serta memposisikan diri mereka sebagai perempuan juga. 
perilaku seksual waria berada dalam satu pemahaman relasi seksual yang dilakukan bersifat homoseks, sementara kode-kode sosial memandang relasi seksual memiliki keabsahan apabila dilakukan secara heteroseks atau perilaku seksualitas dengan lawan jenis. Oleh karena itu, bisa dikatakan perilaku seksual yang dimiliki oleh waria merupakan penyimpangan.

\section{METODE PENELITIAN}

Penelitian ini adalah penelitian yang bersifat kualitatif. Pendekatan yang dipergunakan adalah pendekatan sosiologi sastra sastra. Pada penelitian ini peneliti menggunakan metode deskriptif analisis. Penelitian ini berusaha menguraikan atau mendeskripsikan data-data tertulis baik dari suatu individu atau kelompok tertentu yang dapat diamati serta berusaha untuk menjelaskannya guna memberikan pemahaman.

Data pada penelitian ini berupa hasil telaah dari novel Taman Api Karya Yonathan Rahardjo. Sumber data primer dalam penelitian ini berupa novel Taman Api karya Yonathan Rahardjo. Sumber data sekunder yang dalam penelitian ini adalah sumber data kepustakaan yaitu berupa buku, jurnal, artikel.

Teknik pengumpulan data menggunakan teknik Content analysis, yang merupakan strategi untuk menangkap pesan karya sastra. Teknik validitas data yang dipergunakan dalam penelitian ini adalah teknik trianggulasi data atau sumber, yakni membandingkan dan mengecek balik derajat kepercayaan suatu informasi dari narasumber satu dengan lainnya dan yang diperoleh melalui catatan atau arsip dan dokumen yang memuat catatan yang berkaitan dengan data yang dimaksudkan peneliti (Sutopo, 2002: 79). Teknik analisis adalah analisis model interaktif (Interactive Model Analysis). Menurut Miles dan Huberman (dalam Sugiyono, 2009: 247) terdapat tiga komponen analisis yakni (1) Reduksi Data, (2) Penyajian Data, (3) Penarikan Kesimpulan.

\section{HASIL DAN PEMBAHASAN}

Waria merupakan sebagian dari banyak fenomena. Waria, wadam atau banci merupakan laki-laki yang mengubah bentuk tubuh serta perangainya serupa layaknya lawan jenis atau perempuan (transeksual). Keberadaan waria selain sebagai fenomena juga dianggap sebagai kelompok yang kerap menganggu kenyamanan pastoral masyarakat. Populasi waria semakin menjamur di berbagai pelosok negeri seiring bertambahnya tahun. Pada survey tahun 2008, Yulianus Rettoblaut selaku Ketua Forum Waria Indonesia menjelaskan terdapat sekitar tujuh juta kaum waria di Indonesia.

Waria dengan segala masalah dan gaya hidupnya yang komplek acap kali menjadi masalah bagi sebagian besar masyarakat dan sering dibicarakan sekaligus kontroversial. Satu posisi waria ditolak bahkan tidak diakui keberadaan mereka dalam masyarakat pada umumnya dengan berbagai macam argumentasi baik yang bersifat normatif, psikologis, agama, bahkan kaum merekapun tidak diakui oleh sebagian masyarakat. Satu sisi yang lain, mereka tetap adalah anggota masyarakat dengan segala keterbatasan dan kelebihannya yang tentunya memiliki hak-hak yang sama layaknya masyarakat lain pada umumnya.

Kehidupan seks kaum waria yang dianggap menyimpang dalam novel Taman Api menarik untuk dikaji dan dideskripsikan dalam artikel ini. Hubungan seks merupakan kebutuhan 
biologis manusia pada umumnya. Tidak ubahnya dengan masyarakat normal, mengingat waria juga bagian dari sebuah masyarakat, maka waria juga memiliki keinginan dan dorongan seksualitas. Dorongan seksualitas kaum waria tidak jauh berbeda dengan dorongan seks manusia secara umum, yang menjadi pembeda ialah mengingat waria pada dasarnya merupakan lakilaki dan berperangai layaknya perempuan. Kenyataan tersebut mempengaruhi perilaku seks kaum waria. Berikut temuan dalam novel Taman Api terkait penyimpangan perilaku seks waria.

\section{Hubungan Sesama Jenis}

Layaknya homoseks hubungan seksualitas kaum waria merupakan hubungan seks dengan relasi seksual sesama jenis. Perbedaannya, waria berusaha mengkondisikan dan memposisikan dirinya sebagai seorang wanita dengan segala atribut dan anatomi tubuh laki-lakinya dirubah menjadi layaknya seorang wanita. Berikut kutipan yang menegaskan penyimpangan perilaku seksual waria dengan sesama jenis:

"Malam kian merangkak. "Besok kita sudah pulang 'kan, Mas..? Tanya Tari di awal kebersamaan di kamar hotel mewah yang selanjutnya diiringi perbuatan malam penghangat tubuh di atas kasur empuk menggelombangkan kain seprai, menyisakan bercakbercak basah dalam embusan dingin udara ruang, mewariskan aroma khas dan istimewa." (Taman Api: 19)

Pada kutipan di atas terlihat bagaimana waria Tari melakukan hubungan seksual dengan Ranto seorang dokter spesialis bedah kelamin yang juga merupakan laki-laki. Jelas terlihat bagaimana penyimpangan perilaku seksualitas antara keduanya. Hubungan seks diakui keabsahannya dalam masyarakat jika relasi seksual itu dilakukan secara heteroseksual atau hubungan seksual antara laki-laki dan perempuan. Wujud data lain yang menunjukkan hal serupa juga terlihat pada kutipan berikut.

"Meski mereka semata-mata
manusia yang berjenis sama,
namun perbdaannya, yang satu
alami, sedang yang satu sudah
mengubah penampilan diri
menjadi punya organ-organ lain
pembentuk tubuh dan diri laksana
putri. Dan dalam gelap itu, semua
menjadi alam lain penuh
khayalan." (Taman Api: 134$)$

Kutipan di atas menunjukkan bagaimana waria sebagai transeksual memiliki perilaku seks layaknya homoseks. Kaum waria melakukan hubungan seks dengan pasangan (sebagian besar konsumen) dengan menggunakan alat kelamin yang sama. Mengingat fenomena tersebut, berbagai cara dipergunakan waria demi melampiaskan dorongan seks mereka. Salah satu metode yang dipergunakan waria dalam praktik relasi seksual yakni dengan metode anal atau tindakan seks yang melibatkan masuknya alat kelamin pria ke dalam anus pasangan seksual. Berikut kutipan yang menegaskan adanya penyimpangan perilaku seks waria dengan relasi seksual dengan metode anal.

"Nah, itu'kan?" celetuk Riris, namun tak digubris dokter yang terus mencocor dengan uraian, "Penularan lewat cairan sperma dan cairan vagina misalnya melalui hubungan seks, penis masuk ke dala vagina atau anus 
tanpa menggunakan kondom. Ini memungkinkan tercampurnya cairan sperma denga cairan vagina atau darah, yang mungkin terjadi dalam hubungan seks lewat anus seperti yang kerap kalian lakukan." (Taman Api: 75).

Koeswinarno mengemukakan bahwa praktik relasi seksual dengan menggunakan metode anal juga menjadi salah satu dari empat metode yang dipergunakan waria saat berhubungan dengan pasangan atau konsumen selain metode oral, jepit, dan onani (2004: 58). Pada penelitian koeswinarno dijelaskan bahwa hubungan seks yang menggunkan metode anal tidak begitu berkembang di kalangan waria dan konsumen, kecuali mereka yang benarbenar memiliki hubungan pacar dengan waria tersebut. Pasangan relasi seksual yang ingin melakukan metode anal adalah mereka yang memiliki kecenderungan kea rah homoseks atau penyuka sesama jenis.

\section{Dunia Prostitusi}

Sebagai kaum waria yang dianggap oleh masyarakat sebagai kaum yang mengalami kegamangan gender dan banyak perilaku yang tidak sesuai dengan kodratnya sebagai laki-laki termasuk perilku seks mereka yang menyimpang setelah pilihan hidup yang dianggap menyimpang mengakibatkan kaum waria termarjinalkan dari masyarakat. Kaum waria dianggap sebagai warga kelas dua oleh pemerintah dan tdak diakui eksistensinya pada lembaga-lembaga formal bahkan tidak diakui keberadaan mereka walaupun keyataannya tetap hidup da ada di tengah masyarakat.

Kecenderungan tersebut membuat kaum waria mengalami kesulitan dalam mendapatkan pekerjaan, selain membuka usaha salon yang kerap menjadi pilihanlapangan pekerjaan untuk waria, pada akhirnya dunia malamlah yang sebagian besar menjadi tujuan akhir mata pencaharian mereka di samping untuk mencari kenikmatan atau kepuasan biologis pemuas nafsu dan kepuasan diri. Berikut terdapat kutipan yang menegaskan penyimpangan perilaku seks waria dengan menjadi pekerja malam.

"Bahkan kita jadi hiasan... dan kumbang-kumbang itu dating dan menikmat kita sesuai dengan perjanjian...., papar Susi." (Taman Api: 95)

"He..., bukanlah kalau siang kamu buka salon?" Iya Sih... Maksudku untuk kenikmatan.... Kebutuhan biologis.... Makanan Jiwa..., ujar Meti berubah posisi tidak lagi menghadap tubuh pada Susi." (Taman Api: 95)

"Kok tidak bekerja di suatu tempat, misalnya salon saja?" Tidak. Karena kalau tidak begini, berarti aku menjalani kewariaan secara setengah-setengah. Dengan cara ini, aku merasakan suatu kepuasan." (Taman Api: 98)

Terlihat dalam beberapa kutipan di atas terdapat data yang menegaskan bahwa waria menjalani praktek seks dengan relasi seksual bukan hanya untuk mencari penghidupan atas diri mereka masing-masing. Sejalan dengan itu, waria menjajakan dirinya di malam hari karena dorongan biologis seksualitas-nya. Terlepas dari itu, salah satu tujuan waria menjajakan diri ialah sebuah kesenangan atau hobi. Selain itu, memasuki dunia prostitusi bagi meraka juga kerap dijadikan sebuah seni. Dikatan seni karena setiap hari dapat berganti-ganti relasi seks, berganti-ganti baju dan parfum serta mendapatkan 
uang dengan mudah (Puspitosari dan Pujileksono, 2005: 112). Fenomena ini sudah melekat dan kiranya sudah mendarah daging dalam dunia waria. Puspitosari dan pujileksono (2005: 112) mengungkapkan bahwa dunia prostitusi atau pelacuran bagi kaum waria sudah menjadi budaya tersendiri bagi kehidupan kaum waria.

\section{Rekonstruksi Tubuh}

Penyimpangan perilaku seks pada waria tidak hanya berorientasi pada kenikmatan dengan relasi seks saja. Seks memiliki arti secara harfiah adalah hal yang berhubungan dengan alat kelamin. Hubungan dengan alat kelamin tersebut dapat diambil definisi bahwa seorang laki-laki yang merasa dirinya wanita dan terjebak dalam tubuh pria. Sehubungan dengan itu penyimpangan perilaku seks waria juga erat berhubungan dengan bentuk fisik jasmaninya.

Kaum waria sebagian besar banyak yang melakukan rekontruksi bentuk tubuh ataupun wajah. Hal ini dilakukan karena kesadaran dan didasari oleh bentuk jasmani atau biologis mereka yang memiliki ciri-ciri fisik lelaki. Karena banyak diketahui bahwa waria berupaya mempresentasikan diri mereka adalah perempuan, baik secara perilaku ataupun bertutur. Oleh karena itu, berbagai upaya untuk mendapatkan ciri-ciri tubuh layaknya perempuan tidak bisa dikesampingkan oleh kaum waria ini. Hal tersebut juga memiliki fungsi sebagai salah satu cara masyarakat mengidentifikasikan bagaimana identitas mereka dalam sebuah masyarakat. Hal ini senada dengan yang dikemukakan Abdullah (1995: 45) bahwa tubuh manusia itu sangatlah penting karena sebagai salah satu alat dalam identifikasi sosial. Berikut kutipan yang menegaskan perilaku waria yang merekontruksi tubuh sebagai wujud penyimpangan perilaku seks.

"Tiga orang waria berjajar,
bersolek, celana wanita yang
mereka kenakan meliukkan
pinggul sampai bawah lutut,
namun ujungnya hamper tidak
menutupi betis kuning. Alas kaki
mereka sepatu hak tinggi,
mendukung gaya tubuh menarik
bokong ke belakang dan
mendorong buah dada maju. Di
atas semua itu, wajah mereka
cantik meski gurat kelelakian
terasa." (Taman Api: 6 )

Pada kutipan di atas terlihat bahwa adanya usaha waria untuk mempercantik diri mereka dan mengidentifikasikan bahwa mereka adalah wanita, atau setidaknya berusaha tampil cantik layak-nya wanita. Usahausaha yang dilakukan adalah seperti mempergunakan make up layaknya wanita umumnya, bahkan mempergunakkan baju wanita yang mempertegas lekuk tubuh. Usaha lain yang dideskripsikan oleh koeswinarno (2004: 59) guna menjelaskan bagaimana usaha waria merekontruksi tubuh demi menciptakan kontruksi sosial bahwa kaum waria ingin di pahami sebagai "perempuan" ialah seperti menghilang-kan bulu kaki, merubah suara dan bergincu.

Selain itu, terdapat pula usaha rekontruksi tubuh yang dapat dikatakan lebih berani. Rekontruksi tersebut berhubungan dengan merombak bagian tubuh waria yang memiliki ciri-ciri fisik laki-laki menjadi ciri-ciri fisik perempuan. Hal itu terlihat pada beberapa usaha waria yang merrekontruksi bagian dada, wajah, ataupun pinggul mereka. Perhatikan kutipan berikut.

"Meski secara pembawaan ciri tubuhku tidak sebagaimana laki- 
laki macho dan cenderung punya ciri keperempuan-perempuanan, aku juga mengkonsumsi pil hormon wanita selama berbulanbulan. Tiap hari, aku minum tiga kali satukali minum tiga butir. Pengaruhnya, pada permulaan hanya sedikit perubahan di tubuhku. Kulitku menjadi jauh lebih lembut seperti kulit wanita. Minum pil saja tidak cukup, aku juga suntik hormon. Sedikit demi sedikit payudaraku lebih membesar. Pinggul keluar lebih lebar disbanding sebelumnya. Otot-otot tubuh lebih rata dan kulit lebih putih tubuhku menjadi lebih seksi dan aku kian percaya diri tampil sebagai perempuan." (Taman Api: 8)

Suntik hormon pun kerap dilakukan untuk mendapatkan tubuh yang menjadi idaman. Selain temuan data di atas, terdapat pula data dalam novel Taman Api yang menunjukkan berbagai upaya untuk merekontruki tubuh. Waria kerap melakukan suntik silicon demi memperbesar payudara dan berbagai operasi untuk mengubah bentuk anatomi tubuh. Berbagai alat-alat medis yang mendukung upaya-upaya kaum waria untuk merubah penampilan diperguna-kan seperti suntikan silicon jeli untuk mengisi implant payudara, dan silicon padat untuk testis tiruan serta implant hidung dan pipi, tidak ketinggalan bagi mereka yang memiliki dana lebih, memilih untuk operasi kelamin. Untuk satu ini hanya bagi mereka yang memang menginginkannya.

Hasil analisis yang didapat dari novel Taman Api tersebut juga didukung hasil penelitian Koeswinarno (2004: 59) yang menunjukkan bahwa waria juga melakukan rekontruksi bagian-bagian tubuh yang kerap dilakukan untuk mempercatik penampilan. Bagian-bagian tubuh tersebut misalnya dagu, pipi, payudara, hidung atau pantat. Rekontruksi dapat dilakukan dengan operasi plastic ataupun suntik silicon apabila ingin mendapatkan harga yang lebih murah. Perhatikan kutipan berikut.

"Meski nona Tari punya lipatan
seperti alat kelamin wanita,
karena alat kelamin pria di
atasnya lebih besar, dengan
panjang dan besar termasuk
normal meski di batas bawah,
sama saja, kita bekerja membuang
alat kelamin prianya terlebih
dahulu disusul pembuatan alat
kelamin wanita." (Taman Api: 47)

Kutipan di atas menunjukkan adanya wujud atau upaya merekontruksi bagian tubuh yakni alat kelamin waria Tari dengan jalan operasi bedah kelamin. Digamrkan pula dalam novel Taman Api bahwa rekontruksi kelamin bagi kaum waria diperuntukkan bagi mereka yang berkeinginan untuk mengubahnya, meskipun dalam penceritaannya di-bubuhi adanya praktek bongkar kelamin secara paksa. Oleh sebab itu kaum waria disebut sebagai kaum transeksual. Dikisahkan oleh Yonathan Rahardjo dalam novelnya bahwa banyak waria yang memilih organ vital lelaki mereka tetap ada meskipun dengan organ vital sekunder (payudara) membesar seperti layaknya wanita tetap mereka berlakukan. Berikut kutipan yang menegaskan perilaku seks menyimpang dengan melakukan relasi seks berkelamin lelaki dengan organ vital sekunder layaknya perempuan.

“ Aku normal padahal sudah suntik silicon yang membuat payudaraku tidak asli lagi? Tapi 
paling tidak, dengan kondisi tubuh seperti ini, aku merasa sempurna melakukan segala bentuk hubungan seks sebagai waria yang berpenampilan wanita meski tanpa operasi kelamin. Dan sebetulnya, aku ingin tetap menjadi manusia dengan kondisi apa adanya." (Taman Api: 100)

Sebuah kenyataan waria tetap memiliki dorongan seksual layaknya manusia pada umumnya, meskipun banyak perbedaan-perbedaan yang sering dikatakan sebagai penyimpangan. Kutipan di atas juga menegaskan bahwa tidak smua waria yang alat kelamin primer mereka dirubah menjadi layaknya perempuan meskipun penampilan dan perangai mereka layaknya perempuan.

\section{SIMPULAN}

Berpijak dari uraian yang telah dijelaskan maka dapat disimpulkan dalam novel Taman Api karya Yonathan Rahardjo terdapat data penyimpanganpenyimpangan perilaku seks waria. Penyimpangan perilaku seks tersebut digambarkan oleh tokoh dalam novel tersebut dan terbagi menjadi beberapa bagian. Penyimpangan-penyimpangan perilaku seks tersebut antara lain (a) penyimpangan perilaku seks hubungan sesama jenis, (b) penyimpangan perilaku seks dalam dunia prostitusi, dan (c) penyimpangan perilaku seks rekontruksi tubuh.

\section{DAFTAR PUSTAKA}

Abdullah, I. (1995). Tubuh, Kesehatan dan Reproduksi Hubungan Gender. Populasi No. 6 Vol. 2, 45. Yogyakarta: Pusat Penelitian Kependudukan UGM.
Endraswara, S. (2013). Metodologi Penelitian Antropologi Sastra. Yogyakarta: Penerbit Ombak

Isnaniah, S., Waluyo, H. J., Sayuti, S. A., Andayani. (2013). The Representation of Islamic Teaching in The Novels by Habiburrahman El Shirazy (The Study of Literary Sociology and Education Values). Journal of Education and Practice, Vol.4, No.13, pp.197-198.

Koeswinarno. (2004). Hidup Sebagai Waria. Yogyakarta: LKIS

Nurgiyantoro, B. (1995). Teori Pengkajian Fiksi. Yogyakarta: Gadjah Mada University Press.

Puspitosari, H., Pujileksono, Sugeng. (2005). Waria dan Tekanan Sosial. Malang: UMM Press

Rahardjo, Y. (2011). Taman Api. Jakarta: Pustaka Alvabet.

Sadewa, I. K. (2012). Sajak "Nyanyian Angsa" Karya WS. Rendra: Analisis Antropologi Sastra. Jurnal Pustaka Volume XII, No. 1 , pp. 65-66

Sariban. (2009). Teori dan Penerapan Penelitian Sastra. Surabaya: Lentera Cendekia

Sugiyono. (2009). Penelitian Pendidikan (Pendekatan Kuantitatif, Kualitatif, dan $R \& D)$. Bandung: Alvabeta.

Sutopo. (2002). Metodologi Penelitian Kualitatif: Dasar Teori dan Penerapannya dalam Penelitian. Surakarta: Sebelas Maret University Press.

Wellek, R dan Warren, A. (1990). Teori Kesusastraan. Jakarta: PT. Gramedia 